\title{
The Interest and Strategy of the Syrian Kurds in the Post-Syrian Uprising 2011
}

\author{
Nadia Sarah Azani ${ }^{1}$, Yon Machmudi ${ }^{2}$, Mulawarman Hannase ${ }^{3}$ \\ $\left\{{ }^{1}\right.$ nadia_adzani@ymail.com, ${ }^{2}$ machmudi@ui.ac.id, ${ }^{3}$ mulawarmanhannase@ac.ui.id $\}$ \\ ${ }^{1,2,3}$ School of Strategic and Global Studies, Universitas Indonesia, Indonesia
}

\begin{abstract}
This research focused on the Kurdish people as one of the actors who have an interest in the Syrian political turmoil. In this study, Doug McAdams' social movement theory and the Communalism theories of Murray Bookchin, Robert Melson, and Howard Wolpe are utilized as the framework to analyze the interests and strategies of Kurdish groups in Syria. This research uses a qualitative method, specifically the descriptive-analytical, and the obtained data comes from primary and secondary sources. The results of this study is the interests of the Syrian Kurds that is to establish an autonomous government in Syria in the form of a federation and based on the democratic values that can support the Kurds' rights in Syria. The strategy pursued by Kurdish Syrian groups, especially from The Democratic Union Party (PYD), is to take advantage of the condition of Syrian political instability by declaring an autonomous government in Rojava.
\end{abstract}

Keywords: Kurds, Syria, Arab Spring, Kurdistan Democratic Party of Syria, $P Y D$.

\section{INTRODUCTION}

The Kurdish people are often known as the people without a state that inhabits several states in the Middle East region, such as Turkey, Iraq, Iran, and Syria. In Syria, the Kurdish people minority, which is considered as the minority, have experienced discrimination in social, political, and cultural aspects since the establishment of the Syrian state in 1946. In social relations reality, Kurdish group is categorized as a marginalized group who cannot freely obtain political rights. Kurdish group also often has no access to express its ethnicity and culture. Ethnic issues, which are among Kurds and Arabs ethnic, are the main cause of the conflict. In the era of al-Assad's regime, since Hafez al-Assad reigned in the 1970s, many of the Kurdish groups did not have citizenship status (Caves, 2012: 2).

The Arab Spring phenomenon in Syria in 2011 sparked protests in cities such as Homs, Idlib, Daraa and Damascus as well as the protests against the Bashar al-Assad regime, which occurred in Kurdish-dominated cities such as Qamishli, 'Efrin, Dirbasiya, al-Hassaka, Amuda, Ayn al-Arab, Ras al-'Ayn, and Dayr al-Zawr. However, the protests that occurred in Kurdish towns were not as big as the protests that occurred in the other cities. Bashar al-Assad saw that it would be dangerous, so he decided to co-opt the Kurdish minority by granting citizenship to 
200,000 of them (Hossino \& Tanir, 2012: 6). The Syrian Kurds group initially wanted to join Syrian opposition group that is Syrian National Council. However, Kurdish groups actually tend to be cautious or unclear and slow to act in responding the public uprisings against the government. As the result, other Syrian opposition parties often accuse the Kurdish groups of not effectively supporting the Syrian revolutionary movement and have a special connection or interest with the Bashar al-Assad regime (Hossino \& Tanir, 2012: 8). There are three major Kurdish opposition groups in Syria: first, groups belonging the Syrian Kurdish National Council that is supported by Iraqi Kurdish groups; second, groups belonging to the Syrian National Council that is supported by Turkey, the Gulf and the West States,; and, third, the one that joins the National Coordination Body for Democratic Change, which is The Democratic Union Party (PYD) affiliated with Partiya Karkeren Kurdistan (PKK) in Turkey (Hossino \& Tanir, 2012: 8).

This research is important because of the complexity of the Syrian conflict that is caused by the intricateness of the multiple interests from either internal or external groups. From the perspective of opposition groups, there is still a tendency of mutual hostility between Kurds and Arabs ethnic in Syria that is caused by their unhealthy relationship. Moreover, the tendency of conflict occurrence among Kurdish groups in Syria also makes it more complex. In this research, the research question is what are the Kurds' interests in Syria after political turmoil in Syria in 2011 and the strategy pursued by the Kurds to realize their interests?

\section{METHODOLOGY AND THEORETICAL FRAMEWORK}

\subsection{Methodology}

The approach used in this research is qualitative and the analysis is presented by using a descriptive-analytical method. The data collection technique is by studying the primary data sources from printed and electronic books about the development of Kurdish people in the Middle East, especially from political and social aspect as well as from secondary sources derived from books, journals, thesis, news and articles on the Internet.

\subsection{Theoretical Framework}

A Kurdish group is a minority group in Syria just as they are in other three countries, such as Turkey, Iraq, and Iran. Referring to aforementioned explanation, Kurdish ethnic groups often make efforts to gain rights and recognition. The struggle of the Syrian Kurds, such as the discrimination done by the regime and the Syrian Kurds' wish to establish an autonomous region, itself is an expression of class struggle concept as introduced by Karl Marx. In other words, Marx divides society into two classes, which are the bourgeoisie, the ruler of the capital, and the proletarian or the working class (Suseno 1999: 72 ). On the other hand, the concept of class struggle in Islamic Socialism is introduced by Ali Shariati. Ali divides the society into two groups, the oppressors (zalimun) and the oppressed / weak (mustadh'afin). The oppressor group is a group that possesses authority and power in society, which is the mala' group, such as the nobles and aristocrats, and mutraf groups, or the owners of capital. The oppressed group is a marginalized group consists of people whose rights are discriminated by the oppressor groups (Rahnema, 2002: 452).

The oppressed class struggle often results in mass mobilization against the oppressors. In social movement theory of Doug Mc Adams, it is mentioned that the root of the social movement is functionalism that focuses on the structural and psychological aspects can lead to 
the mass mobilization. The relationship between structural tension caused by industrialization, modernization, economic crisis, social inequality, and others that produce public dissatisfaction can implicate on the emergence of collective action (McAdams, 1996).

The Kurdish people struggle in Syria as a politically, economically, socially and culturally oppressed group has created a collective action aimed to change the situation, specifically, to eradicate social discrimination. The aspiration of the Syrian Kurds is to get the right to selfdetermination by being recognized as an equal group and granted access to establish their own autonomous government. This autonomous government was inspired by Democratic Confederalism ideology initiated by Abdullah Ocalan, PKK leader in Turkey, who insists that one of the rights to self-determination for society is the ability to run their own government (Ocalan, 2011: 33). The Democratic Confederalism concept, which is in line with Communalism theory initiated by Murray Bookchin, is a critique of hierarchical governance and capitalistic society as a source of inequality in social life aspects, including economic and political systems (Bookchin, 2006: 102). Communalism, as an alternative to the monopolistic government system, offers a form of federation that runs by local people (Bookchin, 2006: 100). Aside from being an alternative government theory offered by Bookchin, according to Robert Melson and Howard Wolpe (1970), Communalism is a political group that has some characteristics. First, the form of membership is based on the similarity of culture and identity; second, tend to be more differentiated in terms of status and power than to other community groups; third, politically, the demands put forward tend to be different so that it grows a desire for separation and becomes a threat to other society (Melson \& Wolpe, 1970: 1112-1113).

\section{UNDERSTANDING OF THE KURDISH PEOPLE IN THE MIDDLE EAST.}

The Kurdish people or Kurds belong to the Medes tribe that came to Persia (Iran) from the Central Asia region. The Kurds dominated the Persian mountains from 614 to 550 BC. Fourteen centuries later, they embraced Islam after the arrival of the Islamic Arabian forces that came from the mainland into the Persian mountains (Sihbudi, 1991: 136). The Kurdistan region, or the land of the Kurds, is now under the rule of several countries. The northern Kurdistan region is under the rule of Turkey with an area of 194,000 square kilometers, the eastern Kurdistan region is under the rule of Iran with an area of 125,000 square kilometers, the southern Kurdistan region is under the rule of Iraq with an area of 72,000 square kilometers, the area of western Kurdistan is under the rule of Syria with an area of 18,000 kilometers, and the Kurdistan region of Armenia and Azerbaijan with an area of 18,000 square kilometers. Before the World War I, the Kurdistan region was under the reign of two great kingdoms, which are Persian Empire and Ottoman Turkish Dynasty (Gunter, 2004: 197).

The Kurds have long been fighting for the right to self-determination along with the growth of nationalism ideology in their midst. The Kurdish had fought in 1880 when a rebellion led by Kurdish leader, Shaykh Ubaidullah, in the Hakari Province that was under the Ottoman Turks Dynasty reign (Sahide, 2013: 141). However, the Kurds had helped the Ottoman Turks in expanding their territory to Vienna (Jamaludin, 2001: 32). Despite the Sevres Treaty in 1920 which guaranteed the establishment of an independent state of Kurdistan, in reality, it was never realized (Sahide, 2013).

The struggle of the Kurds to gain autonomous territory still continues until today. In Iraq, the Kurds struggle began in 1923 and led by Ahmad Barzani and Mustafa Barzani. This struggle is organized under a political party called Kurdish Democratic Party (KDP) (Sihbudi, 1991: 137). In 1992, the Kurdistan Regional Movement (KRG) was established and held a semi- 
autonomous government in the Iraqi Kurdistan region. The existence of KRG is recognized in 2005. The current KRG president, Massoud Barzani, is a descendant of Ahmad Barzani and Mustafa Barzani (Broker, 2016: 9-11). The Iraqi Kurds success in establishing an autonomous government has an impact on the success of the KRG in developing the broader energy sector. Also, international oil companies begin to invest in Iraqi Kurdistan region. KRG also managed to build a gas pipeline infrastructure in its development. Cooperation with other countries is also started, even with Turkey (Broker, 2016: 11).

The Kurds rebellion in Turkey to get away from Turkey began in 1925 and led by Kurds religious leader, Said Shaykh, but was successfully thwarted by the Turkish government and military (Jamaludin 2001: 33). In 1970, the Kurdish Turks established the Partiya Karkeren Kurdistan (PKK) that perpetrated threats and separatist actions massively in the 1980s (Jamaludin, 2001: 41). In Iran, in 1942, the Kurdish Communist Party of Iran (Komola) that was the first political party formed by the Iranian Kurds was established. In 1945, the Kurdistan Democratic Party of Iran emerged and incorporated all Kurdish movements, including Komola, and proclaimed the establishment of "The Republic of Mahabad" with its president Qazi Muhammad. In 1946, Pahlavi Dynasty disbanded the Republic of Mahabad and executed its leader (Sihbudi, 1991: 137). On the Iranian Islamic Revolution in 1979, Iranian Kurds who politically favored Khomeini demanded the autonomy of the Kurdistan province, the elimination of discrimination in obtaining employment, and a fair share of the oil mining yields. However, the Iranian government did not grant these demands and, as the result, Iran Kurdish support to the government politically was ended (Sihbudi, 1991: 139).

Geographically, Kurdistan is a fertile region that rich of natural resources. Agriculture with profitable economic value and the best tobacco production is located in the Kurdistan region of Turkey and Iraq. River water resources are also abundant in the Kurdistan region of Turkey, while oil resources are abundant in the Kurdistan region of Iraq and Iran (Gunter, 2004: 199). This wealth becomes an important highlight of these countries national interests. Turkey needs the Iraq oil resource while Iraq needs the Euphrates and Tigris river water resources and both resources are widely available in the Kurdistan region (Knappert 1993: 70). Therefore, the sovereign states of the Kurdistan region are responsible for safeguarding its sovereignty from the Kurds' separatist action.

\section{THE SYRIAN KURDS STRUGGLE TO FIGHT AGAINST THE DISCRIMINATION OF THE AL-ASSAD REGIME}

The end of the French mandate on Syria in 1944 had initiated the discrimination against the Kurds who settled in Syria. Under the French mandate, the Kurds were treated equally with the Syrian Arabs, marked by the success of several Kurdish figures who were recruited by France to occupy important positions in politics (Albarazi, 2013: 13). At the same time, the PanArabism ideology, which began to bloom and became the foundation of the formation of the United Arab Republic that united Syria and Egypt in 1958, continued until Syria declared itself as the Syrian Arab Republic in 1973.

Although the Kurds population in Syria has reached more than 12 percent of the Syria population, in the 1973 constitution, it was explicitly mentioned that the Syrian inhabitant was Arab people. The Kurds were not recognized as ethnic minorities in Syria and were forbidden to practice culture and tradition freely. Arabization policy for Kurdish people in Syria was carried out with forced assimilation and the non-recognition of their natural identity in Syria (Montgomery, 2005: 7-8). The Arabization policy was the government attempt to curb the 
possibility of a revolt from the Syrian Kurds that was inspired by the Barzani group in Iraq. Then, the Syrian government restricted the Syrian Kurds access to control the economic sectors and other national resources and sought to separate them from Iraq Kurdish and Turkey Kurdish (Montgomery, 2005: 11). The political, social and economic rights of the Syrians Kurdish were limited by the difficulty in obtaining the right to citizenship, employment, education, and so forth (Montgomery, 2005: 14).

In 1962, the Syrian government held a population census in the Kurdish-dominated alHassakah province. The policy was held during the power transition period from the United Arab Republic to the Baath regime, which ruled until today (Albarazi, 2013: 15). The rationale for the census was the proliferation of Kurdish migration from other regions illegally, especially from Turkey since 1945; the census was needed to identify those who later inhabited several cities in Syria (Albarazi, 2013: 15). In the census, the Kurds must show evidence of having inhabited Syria since 1945 to obtain Syrian citizenship status. As a result, about 120,000 Kurds had lost their citizenship rights because they could not provide such evidence (Albarazi, 2013: 16).

In the cultural sphere, the language used by Syrian Kurds, which is Kurmanji, is not recognized as an official language. Teaching the Kurdish language is also prohibited in educational institutions (Montgomery, 2005: 15). Prohibition of speaking Kurdish, such as in public, at work, even singing Kurdish-language songs at weddings, is imposed. There is also prohibition to name Kurdish children with other than Arabic names and should set up business and residential areas in Arabic. The Kurds New Year Celebration, which is called Newruz and celebrated every $21 \mathrm{March}$, is also prohibited. The Arabization policy that is enforced toward Syrian Kurds aims to eliminate the historical aspects associated with the Kurds in Syria (Montgomery, 2005: 16-17).

The Syrian Kurds political activity and anything related to the Kurds' interests is illegal. Nevertheless, there are about 13 political parties and Kurdish interest groups in Syria that seek to voice their demand for human rights and to demand for the eradication of discrimination (Montgomery, 2005: 17). However, these activities often lead to detention and security forces are also involved. The detention also applies for Syrian Arabs who work as journalists and human rights activists who focus on Kurdish issues (Lowe, 2011: 5). Among the activities related to the interests of the Kurds, on December 10, 2002, coinciding with International Human Rights Day, about 200 Kurds demonstrated in front of the Syrian parliament building; they voiced several demands, such as demanding the citizenship right, the elimination of discrimination and the prohibition of teaching language and culture of the Kurds, and demanding the uphold of human rights in Syria (Tejel, 2009: 113).

In 2003, the changing of political situation in Iraq with the ends of Baath regime in Iraq, and the start of a new hope for the Iraqi Kurds, such as being recognized as a national group, recognition of Kurdish as the official language, and allowing the Iraqi Kurds to exercise cultural rights in 2004, have inspired the Syrian Kurds to fight (Montgomery, 2005: 19). One year later that is on March 12, 2004, a massive mass demonstration took place in Qamishli and demanding the abolition of discrimination against the Syrian Kurds that has been happening for decades. The protests spread to cities, such as Kobane, Aleppo, and Damascus, and resistance from Syrian armed forces is inevitable. The demonstrations that began in Qamishli have become the Kurds first time in conducting massive demonstrations across Syria (Tejel, 2009: 108).

The journey of the Syrian Kurds in demanding their rights have been formally initiated with the establishment of the Kurdistan Democratic Party of Syria (KDP-S) by Osman Sabri with several Kurdish politicians in 1957 (Hevian, 2013: 2). The KDP-S is affiliated with the Kurdistan Democratic Party of Iraq (KDP) in Iraq and the Kurdistan Democratic Party of Iran 
(PDKI) in Iran. In addition to the KDP-S, several parties and Syrian Kurds movements have sprung up and participated in the political and social dynamics among the Syrian Kurds. In fact, however, not all of these groups support each other. There are conflicting interests among Syrian Kurds groups. In 1965, the establishment of Kurdish Democratic Progressive Party in Syria (KDPP), which was initially broke away with the KDP-S, resulting in a rivalry between the two (Hevian, 2013: 9). In 2003, the establishment of Democratic Union Party (PYD), which ideology was affiliated with the PKK in Turkey and has a military wing called Popular Defence Committees (YPG), is opposed to KDPS. PYD is the member of Union of Kurdistan Communities (KCK) that was the lead organization of Turkish PKK ideology supporting groups. KDPP, in its development, has a relatively good relationship with PYD and PKK. In 2005, The Kurdish Freedom Party, often called as Azadi, was established and, in its development, became an opposition group for PYD and YPG. Furthermore, in 2009, the Kurdish Union Party, called as Yekiti, was established and has characteristics as a group that put forward the values of democracy, pluralism and human rights, and supported the creation of an autonomous government for Syrian Kurds, similar to the case with the Kurdish Regional Government (KRG) in Iraq (Hevian, 2013 : 10-12).

\begin{tabular}{|c|c|c|c|}
\hline Party Name & $\begin{array}{c}\text { Year of } \\
\text { Establishment }\end{array}$ & Party Affiliation & Opposition Party \\
\hline $\begin{array}{c}\text { Kurdistan } \\
\text { Democratic Party } \\
\text { of Syria (KDPS) }\end{array}$ & 1957 & $\begin{array}{c}\text { Kurdistan } \\
\text { Democratic Party of } \\
\text { Iraq; Kurdistan } \\
\text { Democratic Party of } \\
\text { Iran; }\end{array}$ & $\begin{array}{c}\text { Kurdish Democratic } \\
\text { Progressive Party in } \\
\text { Syria (KDPP); } \\
\text { Democratic Union } \\
\text { Party (PYD) }\end{array}$ \\
\hline $\begin{array}{c}\text { Kurdish } \\
\text { Democratic } \\
\text { Progressive Party } \\
\text { (KDPP) }\end{array}$ & 1965 & $\begin{array}{l}\text { Democratic Union } \\
\text { Party (PYD); } \\
\text { Patriotic Union of } \\
\text { Kurdistan (PUK) } \\
\text { Iraq; Komala Iran } \\
\end{array}$ & $\begin{array}{c}\text { Kurdistan } \\
\text { Democratic Party of } \\
\text { Syria (KDP-S) }\end{array}$ \\
\hline $\begin{array}{c}\text { Democratic Union } \\
\text { Party (PYD) }\end{array}$ & 2003 & $\begin{array}{c}\text { Partiye Kurkuran } \\
\text { Kurdistan (PKK) } \\
\text { Turki; Kurdish } \\
\text { Democratic } \\
\text { Progressive Party } \\
\text { (KDPP); Patriotic } \\
\text { Union of Kurdistan } \\
\text { (PUK) Iraq }\end{array}$ & $\begin{array}{c}\text { Kurdistan } \\
\text { Democratic Party of } \\
\text { Syria (KDP-S); The } \\
\text { Kurdish Freedom } \\
\text { Party/Azadi, } \\
\text { Kurdistan } \\
\text { Democratic Party of } \\
\text { Iraq }\end{array}$ \\
\hline $\begin{array}{l}\text { The Kurdish } \\
\text { Freedom } \\
\text { Party/Azadi }\end{array}$ & 2005 & $\begin{array}{c}\text { Kurdistan } \\
\text { Democratic Party of } \\
\text { Syria (KDPS) }\end{array}$ & $\begin{array}{c}\text { Democratic } \\
\text { Progressive Party } \\
\text { (KDPP) }\end{array}$ \\
\hline $\begin{array}{c}\text { Kurdish Union } \\
\text { Party }\end{array}$ & 2009 & $\begin{array}{c}\text { Kurdish Regional } \\
\text { Government (KRG) } \\
\text { Iraq }\end{array}$ & \\
\hline
\end{tabular}




\section{SYRIAN KURDS STRATEGIES AFTER THE SYRIAN POLITICAL TURMOIL 2011}

The mass demonstrations, which were occurred massively in many cities in Syria to oppose the government of Bashar al-Assad in 2011, marked the occurrence of Arab Spring in Syria. Syrian civilians' march on the street to protest the regime's actions and demand political change ultimately triggered a bloody tragedy between civilians and the military. The Syrian Kurds made use of the political instability to organize movements for their interests. The Bashar al-Assad regime tried to dampen the emergence of new factions within the Kurdish group by promising them citizenship rights. However, until March 2012, there were only about 6,000 Syrian Kurds citizens who have been granted citizenship (Broker, 2016: 10). In addition, another policy was made by the Syrian government to prevent the demonstration from the Kurds was the inclusion of delegates from the government of the Baath Party, as well as the party itself, in Newroz Festival celebrations on March 21, 2011, despite the prohibition of this festival in the previous years (Hossino \& Tanir, 2012: 3).

Massive demonstrations occurred throughout Syria, including in Kurdish-dominated cities. While the demonstrations in some cities like Damascus, Idlib, Daraa were massively happened, the upheaval against the regime of Bashar al-Assad in the cities inhabited by the Syrian Kurds is not particularly prominent. The notion that the Syrian Kurds is not too serious in opposing alAssad's regime is widely spread among the Arab people. Other regime opposition groups have echoed the accusations that the Syrian Kurds has become the extension of al-Assad's regime in political turmoil since 2011. The reasons of the Syrian Kurds' lack of participation in the beginning of the rebellion against the regime were the memory that occurred at Qamishli that happened to them in 2004 still lingers and has become a scourge for them (Middle East Report, 2013: 7). In responding to accusations imposed by Arab society, the Kurdish groups consolidate and define themselves as a part of the opposition against the al-Assad regime. On October 26, 2011, a Kurdish National Council (KNC) was established by Massoud Barzani, the president of the Iraqi KRG. KNC is an organization that leads more than ten Syrian Kurds groups, one of them is the KDP-S. However, KNC and PYD have declared a feud toward PYD that refuse to join the KNC. One of the factors is the KRG's closeness with Turkey that PYD feared would be the main supporter of KNC. This split made the KNC more involving the outside Syrian Kurds in its performance and the KNC leadership was transferred to Erbil in the Iraqi Kurdistan region (Gunes \& Lowe, 2015: 5).

On the other hand, Syrian Kurds groups incorporated in the KNC initially wanted to join the Syrian National Council (SNC), which was established in Turkey in 2011, that is the organization that leads the opposition against the regime of Bashar al-Assad. Unfortunately, there was a dispute between the two that was caused by the refusal of the SNC at the request of the KNC to establish an autonomous government for the Syrian Kurds after Assad's reign ends. In 2012, the publication of "National Charter: The Kurdish Issue in Syria" that exclude the recognition of Kurdish rights, one of which is the absence of the Kurdish language as a national language as planned when writing the draft, has worsened the relationship between the KNC and the SNC. This situation is aggravated by the KNC accusation toward Turkey of being the one behind the SNC policies and deliberately disuniting Syrian Kurds with other Syrian people (Gunes \& Lowe, 2015: 10).

A few months after the establishment of the KNC, specifically in December 2011, a counterorganization was established because of the Turkish PKK's, called as the National Coordination Body for Democratic Change (Tevgera Kurden Democrat / TEV-DEM), initiation. This 
organization oversees the PKK's affiliated groups in Syria, one of which is PYD (Orhan, 2016: 3). This organization was formed as an effort to counter the influence of the Iraqi Kurds in Syria. However, Massoud Barzani seeks to dampen the rivalry between PYD and KNC, which are the organizations of Iraqi KRG armies, by working together under the Erbil Agreement in July 2012 that focuses on strengthening the armed forces of both sides as well as the establishment of the Supreme Kurdish Council to avoid conflict between the Kurds (Mansour, 2012: 4). In fact, PYD and $\mathrm{KNC}$ tend to run independently in reality.

In July 2012, or shortly after the Erbil Agreement, political instability occurred in the Syrian capital city, Damascus, when an uprising of opposition groups and bomb attacks killed four people from the Bashar al-Assad family; as the results, the Syrian military forces (Syrian Arab Armies) left the Syrian Kurdistan region to consolidate in the capital city (Caves, 2012: 2). PYD and its military wing, YPG, made use of the vacuum in the Syrian Kurdistan region by taking control the Afrin, Kobane, and Cezire areas. In November 2013, PYD established a de facto government in Rojava (northern Syria covering three aforementioned provinces, Afrin, Kobane, and Cezire). The establishment of this autonomous government in the northern Kurdistan region of Syria has exploited the political crisis that occurred in Syria. In its development, PYD became the largest Kurdish organization group in Syria (Broker, 2016: 11-12).

In the development of the Syrian conflict over the past few years, there has been a dynamic relationship among the Kurdish political movements groups in Syria. PYD, as the de facto holder of the autonomous region of Rojava, is rumoured to have close ties to the Bashar alAssad regime, in which this regime has "given" power to PYD and mutual enemies that both parties have, which are the rebel jihadist groups and Turkish (Gunes \& Lowe, 2015: 6). In the report from International Crisis Group 2014, PYD had received material assistance from the Bashar al-Assad regime. This issue is the reason of other Syrian Kurds groups' accusation toward PYD, in which it said that PYD's position tends to be ambiguous and opportunistic in the Syrian Revolution (Broker, 2016: 15).

Politically, Syrian Kurds groups tend to be fragmented despite the similarity of their main interests that is to get the right to self-determination and to be recognized as an equal nation. Inspired by the success of the Iraqi Kurds, which had established the autonomous government in Iraq, the KRG, and the Democratic Confederalism ideology echoed by Abdullah Ocalan, the PKK leader in Turkey, the Syria Kurdish aspire to unite under a democratic government that runs independently but still being the part of Syrian Republic. These interests are explained further by the KNC that demands constitutional recognition of the Kurdish national identity, the abolition of discriminatory laws and policies, such as the ban to speak Kurdish and to establish of Kurdish schools, as well as the decentralized government (Hevian, 2013: 5). A decentralized and federated government is considered as the alternative for the Syrian future, which is certainly in harmony with the interests of the Syrian Kurds who want to be free from all forms of discrimination that they have been experiencing for decades. The interests that have been fought finally paid off with the success of the PYD's strategy in making use of the political situation in Syria, which is by taking over the northern region of Syria and declaring an autonomous government called Rojava.

\section{CONCLUSION}

Political instability in Syria since 2011 has been a momentum for the Syrian Kurds people to show their existences again after the Qamishli events in 2004 and after experiencing many social, political, and cultural discrimination for decades. It is also a moment for the Kurds to realize the importance of establishing an autonomous government despite many disputes 
occurred among Kurdish groups. They utilized the chaotic situation in Syria by launching a strategy of declaring autonomous regions in northern Syria, the Kurdish people of Syria is considered to be quite successful in scoring gold ink in its own history which is a stage of realizing the interests that have been fought for decades.

\section{ACKNOWLEDGEMENT}

This research based on grant scheme of PITTA (Publikasi International Terindeks untuk Tugas Akhir) or also known as Indexed International Publications for Final Projects toward Universitas Indonesia students. Thank you to The Directorate of Research and Community

Engagement of Universitas Indonesia (DRPM UI).

\section{REFERENCES}

[1]. Albarazi, Zahra, "The Stateless Syrians", Report of the Middle East and North Africa Nationality and Statelessness Research Project, Tilburg Universty, 2013

[2]. Bookchin, Murray, Social Ecology and Communalism, Oakland: AK Press, 2006

[3]. Bröker, Laura, Paper: "Any Hope for a Kurdish State? The United States, Germany and the Prospects of Kurdish Self-Determination”, Heinrich-Böll-Stiftung North America, Washington DC, 2016.

[4]. Caves, John "Syrian Kurds and the Democratic Union Party (PYD)", Backgrounder, Institute of Study of War, 2012

[5]. Gunes, Cengiz, dan Lowe, Robert, Research Paper: "The Impact of the Syrian War on Kurdish Politics Across the Middle East", Middle East and North Africa Program, Chatham House, The Royal Institute of International Affairs, July 2015

[6]. Gunter, Michael M. "The Kurdish Question in Perspective", World Affairs, Vol. 166, No. 4, Spring 2004, pp. 197-205

[7]. Hevian, Rodi, "The Main Kurdish Political Parties in Iran, Iraq, Syria, and Turkey: A Research Guide", Middle East Review of International Affairs, Vol. 17, No. 2 Summer 2013

[8]. Hossino, Omar, dan Tanir, Ilhan, "The Decisive Minority: The Role of Syria's Kurds in the Anti-Assad Revolution", Henry Jackson Society Report, March 2012

[9]. Jamaludin, Fahmi, Tesis: "Kebijakan Luar Negeri Turki dalam Mengatasi Masalah Konflik Etnis dengan Bangsa Kurdi”, Ilmu Hubungan Internasional, FISIP Universitas Indonesia, 2001

[10]. Knappert, Jan, "The Kurds: A Brief History”, International Journal on World Peace, Vol. 10, No. 2, June 1993, pp. 67-70

[11]. Lowe, Robert, "Studying the Kurds in Syria: Challenges and Opportunities", Syrian Studies Association Newsletter, Vol. 16 No. 1, 2011

[12]. Mansour, Renad, "The Role of Iraqi Kurdistan in the Syrian-Kurd Pursuit of Autonomy", Report: Al-Jazeera Center for Studies, 2012

[13]. McAdams, Doug, Comparative Perspectives on Social Movements: Political Opportunities, Mobilizing Structures, and Cultural Framings, Cambridge: Cambridge University Press, 1996

[14]. Melson, Robert, dan Wolpe, Howard, "Modernization and the Politics of Communalism: A Theoritical Perspective", The American Political Science Review, Vol. 64 Issue 4, 1970 
[15]. Middle East Report, "Syrian Kurds: A Struggle Within a Struggle”, Middle East Report no 136, Januari 2013

[16]. Montgomery, Harriet, "The Kurds of Syria: An Existence Denied”, Executive Summary, Berlin: Europäisches Zentrum für Kurdische Studien, 2005

[17]. Ocalan, Abdullah, Democratic Confederalism, London: Transmedia Publishing, 2011

[18]. Orhan, Oytun, "Syrian Kurds: Current Political/Military Situation and Foreign Affairs", ORSAM Review of Regional Affairs, No. 48, Agustus 2016

[19]. Rahnema, Ali, Ali Syariati: Biografi Politik Intelektual Revolusioner, Jakarta: Erlangga, 2002

[20]. Sahide, Ahmad "Suku Kurdi dan Potensi Konflik di Timur Tengah", Jurnal Hubungan Internasional, Vol. 2 No. 2, Oktober 2013

[21]. Sihbudi, Riza, Bara Timur Tengah, Bandung: Mizan, 1991

[22]. Suseno, Franz Magnis, Pemikiran Karl Marx Dari Sosialisme Utopis ke Perselisihan Revisionisme, Jakarta:1999

[23]. Tejel, Jordi, Syria’s Kurds, History, Politic, and Society, New York: Routledge, 2009 